Since many of the eggs of Chotogocdia monticola hatch in less than a minute, Townsend's view that the digestive juices act upon the chitin and cause the shell to weaken is probably incorrect. In all probability the digestive juices of the host is perceived by the larva through the micropyle of the egg and immediately the larva endeavors to free itself from the egg.

\title{
BIBLIOGRAPHY.
}

1. Swezey, O. H., 1907. The Sugar Cane Leaf-Roller (Omiodes accepta) with an Account of Allied Species and Natural Enemies. Rept. Exp. Sta. Hawaiian Sugar Planters' Assoc., Div. Ent. Bull. 5, pp. 1-61.

2. Swezey, O. H., 1908. Observations on the Life History of Chatogredia monticola Bigot. Proc. Hawaiian Ent. Soc. II, No. 1, pp. 1-35.

3. Swezey, O. H., 1909. Army Worms and Cut Worms on Sugar Cane in the Hawaiian Islands. Rept. Exp. Sta. Hawaiian Sugar Planters' Assoc., Div. Ent. Bull. 7, pp. 1-32.

4. Townsend, C. H. T., 1908. A Record of Results from Rearings and Dissections of Tachinidæ. Bull. U. S. Dept. Agric. Bur. Ent. Tech. Ser., No. 12, Pt. VI, pp. 93-118.

\section{A QUESTION OF SYNONOMY.}

\author{
By C. S. Ludlow,
}

Army Medical Museum, Washington, D. C.

For some time an Anopheline found in the eastern tropics has been accumulating names in a most unfortunate way, and as the mosquito is proven a very active carrier of malaria, and I myself am partly to blame for this multiplication of names, it seems fit I should try to untangle the synonomy.

When the study of Philippine mosquitos was in its infancy there was sent in to me an Anopheline which, according to the only authority available at the time, ${ }^{1}$ seemed to be Anopheles funestus Giles. This anopheline is common in the Islands and was early seen to be so usually collected in connection with the report of malaria that in $1908^{2} \mathrm{I}$ noted "is taken always when malaria is present or prevalent" and this was so conspicuous that I stated "one specimen in a collection is enough to lead to a suspicion

1 Giles G. M., Gnats or Mosquitos, 1st edition.

${ }^{2}$ Ludlow, C. S., Mosquitos of the Philippine Islands, the Distribution of Certain Species, and their Occurrence in Relation to Certain Diseases. 1908. 
that malaria is present, and even a small number of them is usually accompanied or immediately followed by new cases, the number (of cases) depending largely on the prophylactic control of the station." 1

Nothing occurred to suggest to me that an error had been made in referring this species to $A$. funestus until the spring of 1912, when in discussing some Philippine mosquitos with Dr. Malcolm Watson, Chief Medical Officer, Estate Hospital Association, Klang, F. M. S., who was in Washington at that time, he called my attention to the fact that the dark species under consideration had a light ventral apical portion on the proboscis, and it seemed possible that it was an undescribed species. I gave Doctor Watson specimens of various Philippine mosquitos which he took to Mr. F. W. Edwards (British Museum) for confirmation of my naming, and at once wrote me that what I had called funesta Giles was really christophersi Theob. In the meantime I published a description of the dark specimens as Myzomyia flavirostris.

Mr. Edwards also kindly wrote me in regard to the matter, saying there could be no doubt as to the naming of the species, especially as Mr. Theobald's types in the British Museum were "fortunately in good condition. The type of christophersi has two broad apical bands like your funesta. On the other hand both funesta Giles and listoni Liston have female palpi with three narrow bands," and in a later letter writing in regard to specimens $I$ had sent him, Mr. Edwards writes " $M$. funesta Giles' and ' $M$. flavirostris Ludl.' both, as you suggest = christophersi."

In preparing the manuscript of "Bulletin No. 4, Surgeon General's Office" in 1913, as this species had heretofore been reported to the Medical Corps, U. S. Army as “ $M$. funesta," it seemed wise to retain the name and Giles description and add a footnote explaining the error which had occurred, and giving the correct name and synonomy, which, with the description of flavirostris immediately following, it was believed would make the matter quite clear.

It was therefore a surprise to find Mr. Banks had redescribed this species as A. febrifer $^{2}$ and that Messrs. Walker and Barber in

1 The observations on which these statements were based began in 1901 and therefore covered several years.

${ }^{2}$ Banks, C. S., A New Philippine Malaria Mosquito. The Phil. Jour. Sc., Vol. IX., Sec. D., No. 4, Aug. 1914. 
their Article "Malaria in the Philippines" had referred to its connection with malaria as if that were quite unknown. ${ }^{1}$ The footnote at the end of this article is also definitely misleading as I did not suggest that christophersi=listoni, but showed that whatever else the synonomy might be, it did not include listoni.

Dr. Marshal A. Barber sent me specimens of this mosquito for determination which reached me in beautiful condition, and there can be no doubt that it is the one I had wrongly referred to " $f u$ nesta," that is, it is unquestionably christophersi.

The synonomy of this species as given by Mr. Edwards, and added to by myself and Mr. Banks is therefore-

Anopheles (Myzomyia) christophersi Theobald-alboapicalis Theobald, mangyana Banks, funesta Ludlow non Giles, flavirostris Ludlow, febrifer Banks.

The re-naming of this species by Banks is the more interesting because of the extreme amount of malaria among the Mangyans and that Myzomyia mangyana Banks was described in connection with a recognition of that condition.

In regard to Anopheles rossi Giles. As used by Banks it includes at least three forms-Myzomyia ludlowi Theobald, Myzomyia indefinita Ludlow, Myzomyia parangensis Ludlow, and is therefore nearly as confusing in the reduction of names as is the multiplication of names in the species previously considered.

It is easy to collect data concerning the relationship of these species, which have probably been more or less mis-comprehended.

Mr. Edwards writes me, in regard to specimens I had sent him marked "M. rossi or indefinita?" "I think I mentioned to you my conclusions on this subject but am not sure. They are that indefinita is a variety of rossi representing it in the Philippines and Malaya, the true rossi not occurring further east than India and Ceylon. These specimens, like all I have seen from the Philippines, are indefinita."

Christophers $^{2}$ says that though $N$. ludlowi rather closely resembles $N s m$. rossi the "eggs of the two species are quite dis-

\footnotetext{
${ }^{1}$ Walker, E. L. and Barber, M. A., Malaria in the Philippines. The Phil. Journ. Sc., Vol. IX., Sec. B., No. 5, Sept. 1914.

${ }^{2}$ Christophers, S. R., Malaria in the Andamans. Sci. Mem. by Off. of Med. and San. Depts., Govt. of India (new series), No. 56.
} 
tinct," and Strickland ${ }^{1}$ while not agreeing with Christophers on this point, after having given the differences in the two larvæ, says "the larva of ludlowi is therefore quite distinct from that of rossi" and in a footnote adds "As a certain amount of confirmation, we may note that if either ludlowi or rossi had hatched out of one of our breeding bottles, on examining the larvæ remaining in the bottles we found in every case, although we need not have expected such favorable evidence, that they were of the type which we now ascribe to the respective species."

The description of Myzomyia parangensis has been comparatively lately published, but specimens were sent to Edwards for comparison before its publication and his verdict was "This is quite unlike any anopheline I have seen before. I suppose it comes nearest to ludlowi."

The status of these species seems to be that the anophelines taken in the Philippines which closely resemble rossi are really indefinita, and that ludlowi, and parangensis are established species.

When insects are connected with the transmission of disease it is doubly important that the nomenclature should be as unclouded as possible, and it is hoped the above points may clear some of the confusion which has existed concerning these species. ${ }^{2}$

\title{
DOES THE HOUSEFLY HIBERNATE AS A PUPA?
}

\author{
By Harold Lyon, \\ Bussey Institution, Harvard University.
}

The following experiments were conducted during the past winter to determine if it were possible for the housefly to overwinter in the pupal stage. Thirty-seven lots were obtained, each

\footnotetext{
${ }^{1}$ Strickland, C., The Comparative Morphology of the Anophelines Nyssomyzomyia ludlowi Theob. and Nyssomyzomyia rossi Biles. Bull. Ento. Research., Vol. V, Pt. 4, March, 1915.

2 Since this article was sent to the publisher Mr. Edwards writes that "the name christophersi must be replaced by minimus, Theob. (described rather inaccurately from Hong Kong in 1901.)" The species was afterward referred to Pyretophorus, under which genus it is placed in Bull. No. 4, Surgeon General's Office, p. 46.
} 

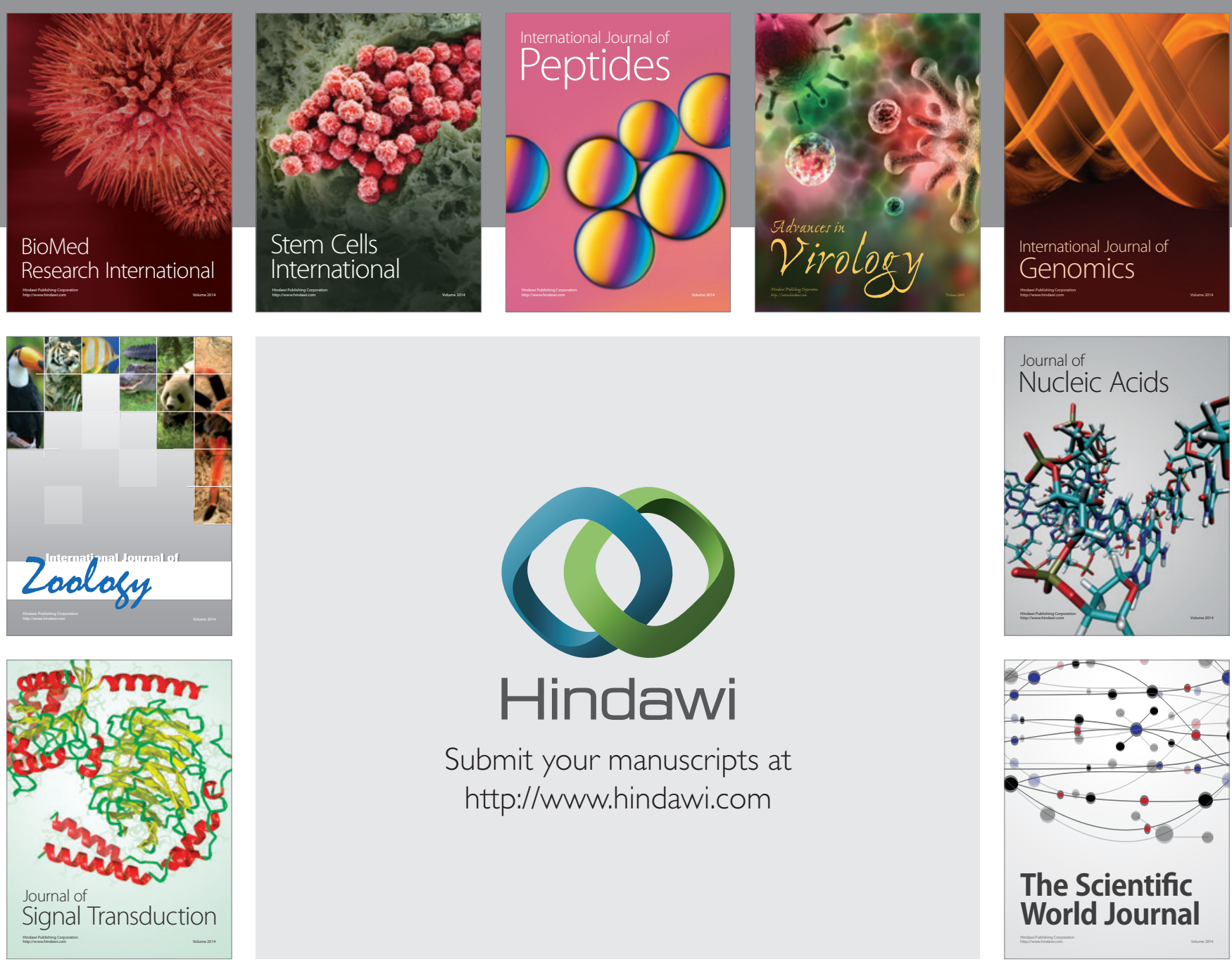

Submit your manuscripts at

http://www.hindawi.com
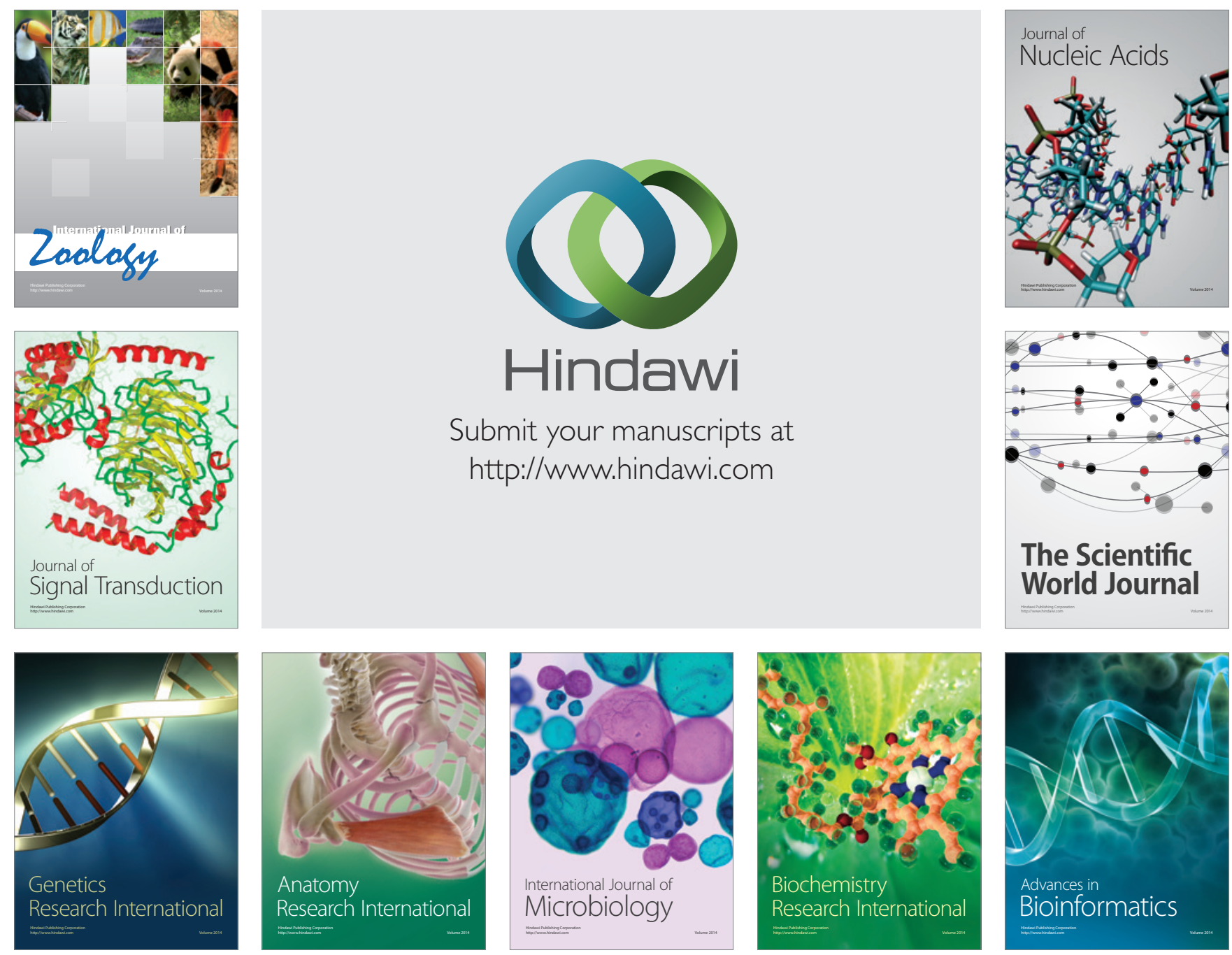

The Scientific World Journal
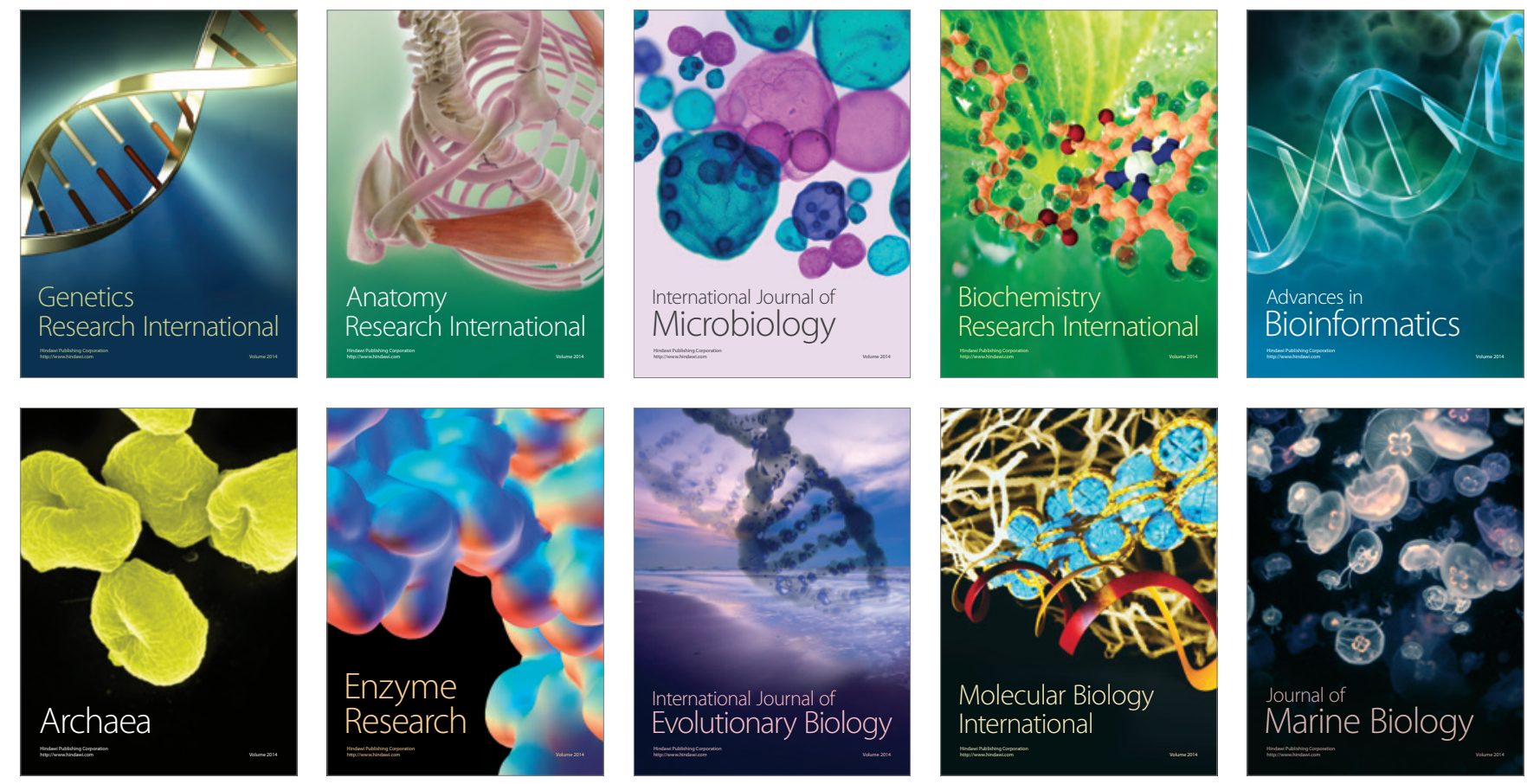